\title{
Обґрунтування та вибір агромашин за обраними робочими органами
}

\author{
В.М. Зубко \\ Сумський національний аграрний університет (м.Суми, Україна) \\ Email: zubkovladislav@ukr.net, ORCID: 0000-0002-2426-2772
}

\begin{abstract}
Розглянуто підходи до обґрунтування алгоритмів визначення складу машинного парку необхідного для виконання механізованих технологічних операцій, на основі визначених типів робочих органів. Досліджено показники для сільськогосподарських машин, які забезпечують якісне виконання основних технологічних операцій: ширина захвату, кінематична довжина і ширина, робоча швидкість, опір агрегатування, потужність на привід робочих органів.

Визначено фактори, що впливають на реальну робочу швидкість виконання кожної механізованої технологічної операції та коефіцієнт використання ширини захвату сільськогосподарських машин. Реальна робоча швидкість виконання кожної механізованої технологічної операції залежить від складу машинного агрегату.

Ширина захвату сільськогосподарських машин залежить від розмірів полів, їх конфігурації, довжини гонів, нахилу місцевості та конструктивної ширини захвату. Коефіцієнт використання ширини захвату сільськогосподарських машин залежить від виду операції, типу робочого органу та від обмежень за агротехнічними вимогами. Аналіз проведених досліджень показує, що залежність коефіцієнту використання ширини захвату орного агрегату залежить від швидкості виконання операції і має квадратичний характер. Для машин, які вносять засоби захисту рослин або проводять підживлення по листку, коефіцієнт використання ширини захвату залежить від висоти встановлення фрорсунки над поверхнею ґрунту і кутом розпилення рідини.

Розглянуто фрактори що впливають на потужність необхідну для приводу робочих органів збиральних машин.

Все перелічене необхідно враховувати при створенні математичних моделей, для процесу вибору оптимального складу машинного парку, спираючись на попередньо визначені типи робочих органів.
\end{abstract}

Ключові слова: агромашина, робоча швидкість, технологічна операція, потужність, робочий орган.

Постановка проблеми. Одне з найважливіших завдань фрахівців інженерної служби полягає у визначенні для кожного окремого підприємства такої оптимальної кількості машин, яка забезпечить найефективніше виконання необхідних технологічних операцій.

В обґрунтуванні комплексів машин, що складають машинно-тракторний парк, важливою умовою $є$ забезпечення агротехнологічних вимог і строків виконання технологічних операцій. Це дає можливість виконання виробничих процесів на необхідному технологічному рівні та одержання максимально запланованої кількості продукції рослинництва.

Основою для вибору агромашин для кожної технологічної операції є визначений тип робочого органу. Аналізуючи розміри поля, його схили, конфрігурацію, умови роботи (перешкоди) та характеристики ґрунту (база полів господарства) і досліджуючи агромашини (бази агромашин), на яких встановлений визначений тип робочого органу, їх призначають для виконання відповідної операції.
Аналіз актуальних досліджень. Машинне забезпечення сучасних підприємств вимагає значного підвищення віддачі від капітальних вкладень і матеріальних ресурсів. Тому велика кількість досліджень спрямовано на визначення кращих підходів до оптимального використання машинного парку. Багато вчених сходяться на думці, що тільки системний аналіз в сполученні 3 математичним моделюванням властивих йому процесів і взаємозв'язків $€$ найбільш ефективним напрямком наукових досліджень в галузі сільськогосподарського виробництва [1, 2, 3, 4, 5.].

У наукових працях академіка Погорілого Л.В. вперше обґрунтовано необхідність застосування системного аналізу для дослідження проблем машиновикористання [1]. Фіном Е.А. запропонована система розрахунків механізованих технологій і комплектування парку машин, яка базується на аналізі обмеженого числа окреслених систем, для оптимізації кожної з яких можуть бути запропоновані моделі і методи, засновані на загальних принципах математичного програмування та імітаційного моделювання [6]. 
Саакян Д.Н. запропонував систему, що передбачає п'ять взаємозалежних груп окремих показників: агротехнічні, експлуатаційні, промислові, економічні, загальнотехнічні, і естетико-ергономічні показники [7]. Загалом його система оцінки машин враховує 70 окремих показників.

В роботах Діденка М.К., Гречкосія В.Д., Мельника І.І. [8] розроблена математична модель, для оптимізації комплексу машин та машинно-тракторних агрегатів при виконанні окремрї операції або технологічного процесу в цілому в залежності від обсягів виробництва або площі вирощування культури. Під керівництвом професора Мельника I.І. розроблена й впроваджена у виробництво та навчальний процес система "Комплексне машиновикористання", що дозволяє вирішувати задачі з обґрунтування складу комплексів машин і структури машинного парку в єдиному системному взаємозв'язку [9].

Мета статті полягає в обґрунтуванні алгоритмів визначення складу машинного парку необхідного для виконання механізованих технологічних операцій, на основі визначених типів робочих органів.

Виклад основного матеріалу. Загальними показниками для агромашин $€$ показники, які забезпечують якісне виконання робіт. В залежності від виду робіт, показники також різні. Наприклад:

- для агромашин, які забезпечують виконання основних технологічних операцій: ширина захвату, кінематична довжина і ширина, робоча швидкість, опір агрегатування, потужність на привід робочих органів.

- для навантажувально-розвантажувальних агромашин: об'єм ковша, вантажопідйомність, щільність матеріалу, висота навантаження, потужність на привід робочих органів;

для транспортних:

- агрегати: робоча швидкість, вантажопідйомність, об'єм кузова;

- автомобільні: робоча швидкість, вантажопідйомність, об'єм кузова.

Допустима робоча швидкість агромашин залежить від операцій, типу робочого органу та від обмежень за агровимогами (таблиця 1).

Реальна робоча швидкість виконання кожної механізованої технологічної операції залежатиме від складу машинного агрегату.

Ширина захвату агромашин залежить від розмірів полів, їх конфігурації, довжини гонів, нахилу місцевості та конструктивної ширини захвату. Робоча ширина захвату агромашин становить [10]:

$$
\mathrm{B}_{\mathrm{p}}=\mathrm{B}_{k} \cdot \beta,
$$

де $\mathrm{B}_{k}$ - конструктивна ширина захвату, $M$; $\beta$ - коефіцієнт використання ширини захвату.
Коефіцієнт використання ширини захвату агромашин залежить від виду операції, типу робочого органу та від обмежень за агровимогами (табл. 2).

Таблиця 1 Допустимі швидкості для основних механізованих технологічних операцій

\begin{tabular}{|l|c|l|}
\hline $\begin{array}{l}\text { Механізовані тех- } \\
\text { нологічні операції }\end{array}$ & $\begin{array}{c}\text { Робоча } \\
\text { шм/год. }\end{array}$ & \multicolumn{1}{|c|}{$\begin{array}{c}\text { Обмеження } \\
\text { швидкості }\end{array}$} \\
\hline $\begin{array}{l}\text { Дискування поля } \\
\text { після кукурудзи }\end{array}$ & $9-10$ & Тип та діаметр диску \\
\hline $\begin{array}{l}\text { Оранка оберто- } \\
\text { вими плугами }\end{array}$ & 12 & Тип полиць \\
\hline $\begin{array}{l}\text { Посів кукурудзи } \\
\text { пневматичним ви- } \\
\text { сіваючим апара- } \\
\text { том }\end{array}$ & $9-12$ & $\begin{array}{l}\text { Галопування, рівно- } \\
\text { мірність посіву по } \\
\text { довжині та глибині }\end{array}$ \\
\hline $\begin{array}{l}\text { Внесення 3зР } \\
\text { та елементів } \\
\text { живлення }\end{array}$ & до 20 & Тип фрорсунок \\
\hline $\begin{array}{l}\text { збирання } \\
\text { кукурудзи }\end{array}$ & $\begin{array}{l}\text { Тип молотильного } \\
\text { пристрою, додаткові } \\
\text { прискорювачі } \\
\text { обмолоту }\end{array}$ \\
\hline
\end{tabular}

Таблиця 2. Коефіцієнт використання ширини захвату для основних механізованих технологічних операцій

\begin{tabular}{|c|c|c|}
\hline $\begin{array}{l}\text { Механізовані } \\
\text { технологічні } \\
\text { операції }\end{array}$ & 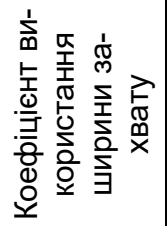 & $\begin{array}{c}\text { Обмеження } \\
\text { коефіцієнта } \\
\text { використання } \\
\text { ширини захвату }\end{array}$ \\
\hline $\begin{array}{l}\text { Дискування поля } \\
\text { після кукурудзи }\end{array}$ & $0,96-0,98$ & $\begin{array}{l}\text { Тип та діаметр диску, } \\
\text { швидкість, якість сиг- } \\
\text { налу GPS }\end{array}$ \\
\hline Оранка плугами & $1,00-1,10$ & $\begin{array}{l}\text { Швидкість, тип по- } \\
\text { лиці, якість сигналу } \\
\text { GPS }\end{array}$ \\
\hline $\begin{array}{l}\text { Посів кукурудзи } \\
\text { пневматичним ви- } \\
\text { сіваючим апара- } \\
\text { том }\end{array}$ & 1,00 & Якість сигналу GPS \\
\hline $\begin{array}{l}\text { Внесення } 33 \text { та } \\
\text { елементів } \\
\text { лення }\end{array}$ & $1,10-1,25$ & $\begin{array}{l}\text { Тип форосунок, сила і } \\
\text { напрям вітру }\end{array}$ \\
\hline $\begin{array}{l}\text { Збирання } \\
\text { кукурудзи }\end{array}$ & 1,00 & $\begin{array}{l}\text { Яка відповідає кіль- } \\
\text { кості рядків при посіві }\end{array}$ \\
\hline
\end{tabular}

У результаті проведених досліджень у польових умовах встановлено, що коефіцієнт використання ширини захвату залежить від швидкості руху машини у складі агрегату (рис. 1). 


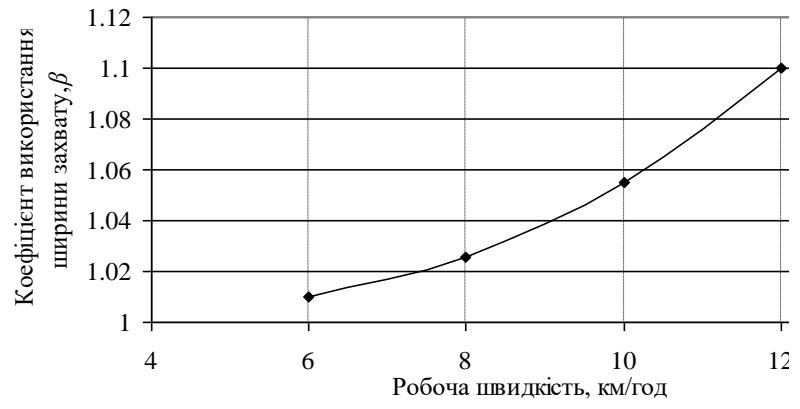

Рис. 1. Залежність коефіцієнту використання ширини захвату орного агрегату від робочої швидкості

Аналіз проведених досліджень показує, що залежність коефріцієнту використання ширини захвату орного агрегату залежить від швидкості їі проведення і має квадратичний характер:

$$
\beta=0,0018 V_{\text {роб }}^{2}-0,0182 V_{\text {роб }}+1,053,
$$

де $V_{\text {роб }}$ - робоча швидкість орного агрегату, км/2од.

Для машин, які вносять 33Р або проводять підживлення по листку, коефіцієнт використання ширини захвату залежить від висоти встановлення форсунки над поверхнею ґрунту і кутом розпилення рідини (рис. 2).

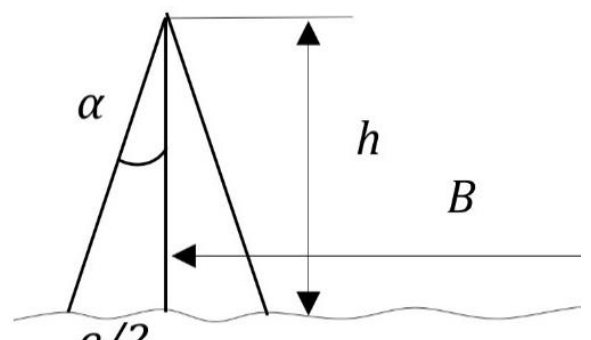

$8 / 2$

Рис. 2. Залежність коефіцієнту використання ширини захвату при обприскуванні від віддалі між рослиною і форсункою та кута розпилу розпилювача (форсунки)

$$
\begin{gathered}
0,5 \mathrm{~B} / h=\operatorname{tg} \alpha, \\
\beta=\mathrm{B}_{\mathrm{p}} / \mathrm{B}_{k}, \\
\beta=\frac{\mathrm{B}_{k}+\mathrm{B}}{\mathrm{B}_{k}}=\frac{\mathrm{B}_{\mathrm{K}}+2 \cdot h \cdot \operatorname{tg} \alpha}{\mathrm{B}_{k}}, \\
\beta=\frac{\mathrm{B}_{k}}{\mathrm{~B}_{k}}+\frac{2 \cdot h \cdot \operatorname{tg} \alpha}{\mathrm{B}_{k}}=\frac{2 \cdot h \cdot \operatorname{tg} \alpha}{\mathrm{B}_{k}}+1, \\
B_{\mathrm{p}}=B_{k}+2 \cdot h \cdot \operatorname{tg} \alpha,
\end{gathered}
$$

де $\mathrm{B}_{\mathrm{p}}$ - робоча ширина захвату, м; $h$ - конструктивна ширина захвату, м (із технічної характеристики); в - ширина розпилення рідини на поверхні ґрунту, м; $\alpha$ - кут розпилу робочої рідини форсункою розпилювача; $\beta$ - коефіцієнт використання ширини захвату.

У виробничих умовах реальна робоча ширини захвату залежатиме від складу машинного агрегату. У зв'язку із застосуванням сучасних навігаційних систем та автоматичного підрулювання, коесріцієнт використання ширини захвату $\beta$ збільшується.

Наступною характеристикою агромашин $є$ їх кінематична характеристика, яка обумовлюється двома показниками (рис. 3):

1 - кінематичною довжиною агромашин;

2 - кінематичною шириною агромашин.

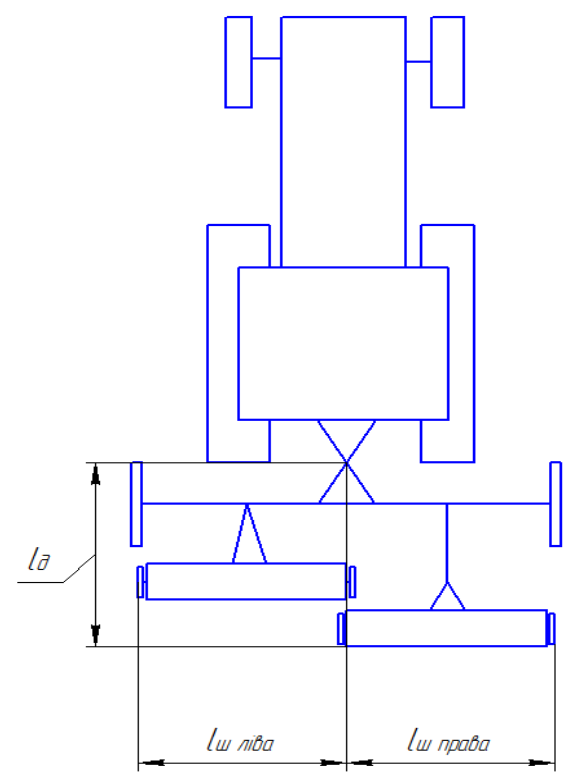

Рис. 3. Кінематична довжина та кінематична ширина для агромашин

Для несиметричних машин кінематична ширина складається із правої та лівої кінематичної ширини. Кінематичні характеристики агромашин впливають на величину холостого ходу при повороті, що в майбутньому відобразиться на їх продуктивності.

Кінематична довжина агромашини - це віддаль від точки причіпу агромашин з енергетичними засобами до крайнього робочого органу.

Надзвичайно важливим показником є загальний опір при агрегатуванні агромашин, який складається з робочого опору, опору на перекочування агромашин та опору на підйом агромашин і визначається із залежності:

$$
R_{\text {заг }}=R_{\mathrm{p}}+R_{f}^{a}+R_{i}^{a}, \mathrm{kH},
$$


де $R_{p}$ - робочий опір, $\kappa H ; R_{f}^{a}$ - опір на перекочування агромашин, $\kappa B m ; R_{i}^{a}-$ опір на підйом агромашин, $к H$.

При умові руху машин під гору (по схилу вниз) опір дорівнює:

$$
R_{\text {заг }}=R_{\mathrm{p}}+R_{f}^{a}-R_{i}^{a}, \mathrm{\kappa H} .
$$

Робочий опір машин залежить від питомого опору ґрунту, який в свою чергу залежить від його твердості, вологості, пористості та швидкості руху агромашин.

Питомий опір для агромашин, робочі органи яких працюють на глибині не більше 14 см, визначається на одиницю ширини захвату:

$$
\begin{aligned}
& k_{V}=k \cdot\left(1+T\left(V_{p}-V_{0}\right)\right) \times \\
& \times\left(1-0,01 \cdot\left(p_{\text {опт }}-p_{\phi}\right)\right) \times \\
& \times\left(1-0,01 \cdot\left(k_{\text {опт }}-k_{\text {क }}\right)\right), \mathrm{\kappa H} / \mathrm{M} ;
\end{aligned}
$$

- для агромашин, робочі органи яких працюють на глибини більше 14 см, визначається через поперечний розріз пласта з урахуванням глибини обробітку та швидкості руху. Як правило, такі машини складаються $з$ набору корпусних робочих органів:

$$
\begin{aligned}
k_{0_{V}} & =k_{0} \cdot\left(1+0.006 \cdot\left(V_{p}^{2}-V_{0}^{2}\right)\right) \times \\
& \times\left(1-0,01 \cdot\left(p_{\text {опт }}-p_{\text {क }}\right)\right) \times \\
& \times\left(1-0,01 \cdot\left(k_{\text {опт }}-k_{\text {क }}\right)\right), \mathrm{\kappa H} / \mathrm{M}^{2} ;
\end{aligned}
$$

де $k, k_{0}$ - відповідно питомий опір агромашин значення, якого стабільне при підвищенні швидкості руху агрегату, кH/M²; $V_{0}$ - гранична швидкість, при якій питомий опір не змінюється, км/2од; $V_{\mathrm{p}}$ - робоча швидкість агрегату, км/год; Т - темп приросту питомого опору для відповід-

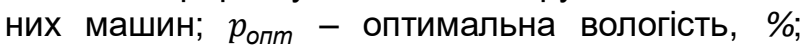
$p_{\phi}$ - фактична вологість, \%; $k_{\text {опт }}$ - оптимальна пористість ґрунту, \%; $k_{\phi b}$ - фактична пористість ґрунту, \%.

Визначення твердості ґрунту проводиться твердоміром Ревякіна або пенетрометрами різних модифрікацій (рис.4)

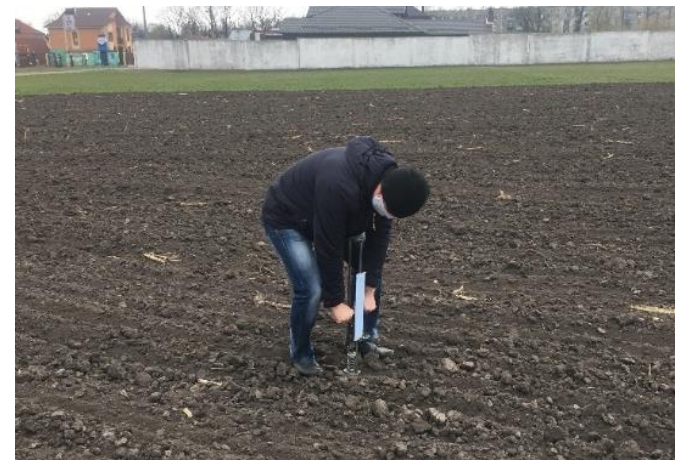

Рис. 4. Визначення твердості ґрунту твердоміром Ревякіна

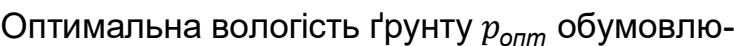
ється типом технологічних операцій. Наприклад, проведення сівби повинно проходити при вологості, яка необхідна для проростання посівного матеріалу [11] (таблиця 3).

Таблиця 3. Оптимальна вологість ґрунту, необхідна для набухання та проростання посівного матеріалу (у \% сухої речовини)

\begin{tabular}{|l|c|}
\hline \multicolumn{1}{|c|}{ Тип рослин } & $p_{\text {опт }}, \%$ \\
\hline Пшениця озима & 47 \\
\hline Кукурудза на зерно & 40 \\
\hline Соняшник & 57 \\
\hline Гречка & 47 \\
\hline Ріпак озимий & 55 \\
\hline Жито озиме & 60 \\
\hline Овес & 68 \\
\hline
\end{tabular}

Пористість ґрунту визначає його структурний стан (чим вищий показник структурованості, тим вища пористість), механічний склад та якість проведення обробітку ґрунту [12] (таблиця 4).

Таблиця 4. Пористість оброблюваних горизонтів

\begin{tabular}{|l|c|}
\hline \multicolumn{1}{|c|}{ Тип ґрунту } & $k_{\text {опт }}, \%$ \\
\hline Торф & 85,2 \\
\hline Піщаний & 30,4 \\
\hline Суглинковий & 45,1 \\
\hline Глинистий & 52,7 \\
\hline
\end{tabular}

Таким чином, питомий опір враховує відповідні агрокліматичні умови.

Робочий опір агромашин складає:

- для агромашин, робочі органи яких працюють на глибині не більше 14 см,:

$$
R_{\mathrm{p}}=k_{V} \cdot B_{\mathrm{\kappa}} \cdot k_{w d}, \mathrm{\kappa H} ;
$$

- для агромашин, робочі органи яких працюють на глибини більше 14 см:

$$
R_{\mathrm{p}}=k_{0 V} \cdot b \cdot a \cdot n_{K}, \mathrm{\kappa H} ;
$$

де $R_{\text {роб }}$ - загальний опір машин, $\kappa H ; b$ - ширина захвату корпусного органу, $м ; a$ - глибина обробітку, $M ; n_{K}-$ кількість корпусних робочих органів, um.; $B_{\kappa}-$ конструктивна ширина захвату звичайних машин, $м$.

Опір перекочування залежить від маси агромашин та коефіцієнта перекочування:

$$
R_{f}=\left(G_{\mathrm{M}}+G_{\mathrm{B}}\right) \cdot g \cdot \cos \alpha \cdot f_{\mathrm{M}}, \mathrm{\kappa H} ;
$$

де $G_{M}$ - маса агромашини, $m ; G_{\theta}$ - маса додаткового вантажу, $m ; g$ - прискорення вільного падіння, $M / c^{2} ; \alpha$ - кута нахилу кривої підйому, 
град; $f_{M}$ - коесіцієнт опору перекочування агромашин, $\kappa H / M^{2}$.

Значення коефіцієнта перекочування $f_{м}$ для активних ходових систем наведений на рис. 20.

Для агромашин, у яких ходові системи пасивні, значення коефіцієнта $f_{M}$ буде більше на 0,010,02, ніж у активних ходових систем.

При роботі агромашин на полях, які мають нахил, додатково виникає опір підйому:

$$
R_{\mathrm{i}}=\left(G_{\mathrm{M}}+G_{\mathrm{B}}\right) \cdot g \cdot \cos \alpha \cdot \operatorname{tg} \alpha, \mathrm{\kappa H} ;
$$

де $G_{m}$ - маса агромашини, $m ; G_{в}$ - маса додаткового вантажу, $m ; g$ - прискорення вільного падіння, $M / c^{2} ; \alpha$ - кута нахилу кривої підйому, град; де $G_{m}$ - маса машини, $m$;

\section{Потужність на привід робочих органів.}

Для реалізації виконання робочого процесу, опорів перекочування та подолання підйому потрібна необхідна потужність, включаючи потужність на привід робочих органів. У загальному вигляді рівняння буде мати вид:

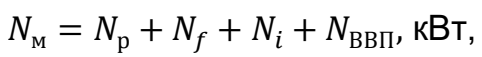

де $N_{M}$ - необхідна потужність для агрегатування та виконання робочого процесу агромашиною, $\kappa B m ; N_{p}$ - потужність на виконання робочого чого процесу, кBm; $N_{f}$ - потужність на перекочування, $\kappa B m ; N_{i}$ - потужність на подолання підйому по схилу, $\kappa B m ; N_{B в п}-$ потужність на привід робочих органів, $к B m$.

Складові потужності визначаються за наступними виразами:

- потужність, необхідна для виконання робочого процесу:

$$
N_{\mathrm{p}}=\frac{R_{\mathrm{p}} \cdot V_{\mathrm{p}}}{3,6}, \mathrm{\kappa BT},
$$

де $V_{p}$ - робоча швидкість агромашин, км/год.

- потужність, необхідна на подолання опору перекочування агромашин:

$$
N_{f}=\frac{R_{f} \cdot V_{\mathrm{p}}}{3,6}, \text { кВт. }
$$

- потужність, необхідна на подолання опору підйому по схилу:

$$
N_{i}=\frac{R_{i} \cdot V_{\mathrm{p}}}{3,6}, \text { кBт. }
$$

- потужність, необхідна на привід активних робочих органів агромашин через ВВП:

$$
N_{\text {ВвП }}=0,1047 \cdot \mathrm{M}_{\kappa р} \cdot n, \mathrm{\kappa BT},
$$

де $N_{\text {ввп }}$ - потужність, необхідна на привід робочих органів, $\kappa B m ; \mathrm{M}_{\text {кр }}$ - крутний момент на валу приводу робочих органів агромашин, $к H \cdot M ; n-$ оберти ВВП, об/хв.
- потужність, необхідна на привід робочих органів агромашин через гідросистему, залежить від потужності гідронасоса і режиму його роботи:

$$
N_{\text {ВВП }}=N_{\text {ш }} \cdot \eta_{ш}, \mathrm{\kappa BT} ;
$$

де $N_{u}$ - потужність гідронасоса, $к B m ; \eta_{u}-$ коефріцієнт, який враховує режим роботи насоса (від номінального до максимального режиму $\left.\eta_{u}=0,75 \div 1,00\right)$.

- потужність, необхідна на привід робочих органів збиральних машин, продуктивність яких вимірюється через пропускну здатність, визначається через питомі витрати потужності на одиницю пропускної здатності:

$$
N_{\text {ВВП }}=N_{\text {пит }} \cdot q, \mathrm{\kappa BT} ;
$$

де $N_{\text {пит }}$ - питома потужність на одиницю пропускної здатності, кBm ·ек/к2; $q$ - пропускна здатність збиральної агромашини, кг/сек.

Маса, яка поступає до збиральної агромашини за секунду роботи $q_{3}$ визначається:

$$
q_{3}=\frac{V_{p} \cdot B_{p} \cdot\left(U_{3}+U_{c}\right)}{36} \text { кг/сек, }
$$

де $V_{p}$ - робоча швидкість агромашини, км/год.; $B_{p}$ - робоча ширина захвату агромашини, $M$; $U_{3}$ - біологічна маса врожаю, $m / 2 a ; U_{c}$ - врожайність зерна агрокультури, $m / 2 a$.

Реальна пропускна здатність збиральної машини залежить від стану біологічного врожаю, в тому числі від виду культури Кул, коефіцієнта соломистості $k_{\text {c }}$, вологості w тощо.

Коефіцієнт соломистості залежить від конкретної агрокультури та її сорту або гібриду:

$$
\begin{gathered}
U_{\mathrm{T}}=U_{3}+U_{\mathrm{c}}, \text { ц/га } \\
k_{\mathrm{c}}=\frac{U_{\mathrm{c}}}{U_{\mathrm{T}}}, \\
U_{\mathrm{T}}=U_{3}\left(1+\frac{k_{\mathrm{c}}}{1-k_{\mathrm{c}}}\right), \text { ц/га }
\end{gathered}
$$

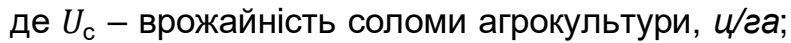
$U_{\mathrm{T}}$ - біологічна врожайність агрокультури, $u / 2 a ;$ $k_{c}-$ коефіцієнт соломистості.

Для прикладу, коефіцієнт соломистості для різних культур наведений у таблиці 5.

За результатами аналізу лабораторно-польових досліджень встановлено характер зміни додаткової пропускної здатності агромашин в залежності від коефіцієнта соломистості $\Delta q_{c}$ :

$$
\Delta q_{c}=2.5791 \cdot \lg k_{c}-0.0117 \text {. }
$$

Зі зменшенням коефіцієнта соломистості, реальна пропускна здатність комбайна збільшується (рис. 5). 
Таблиця 5 Коефріцієнт соломистості для основних агрокультур

\begin{tabular}{|l|c|}
\hline \multicolumn{1}{|c|}{ Культура } & Коефіцієнт соломистості \\
\hline Пшениця озима & 0,72 \\
\hline Кукурудза на зерно & 0,64 \\
\hline Соняшник & 0,63 \\
\hline Гречка & 0,44 \\
\hline Ріпак озимий & 0,33 \\
\hline Жито озиме & 0,70 \\
\hline Овес & 0,89 \\
\hline
\end{tabular}

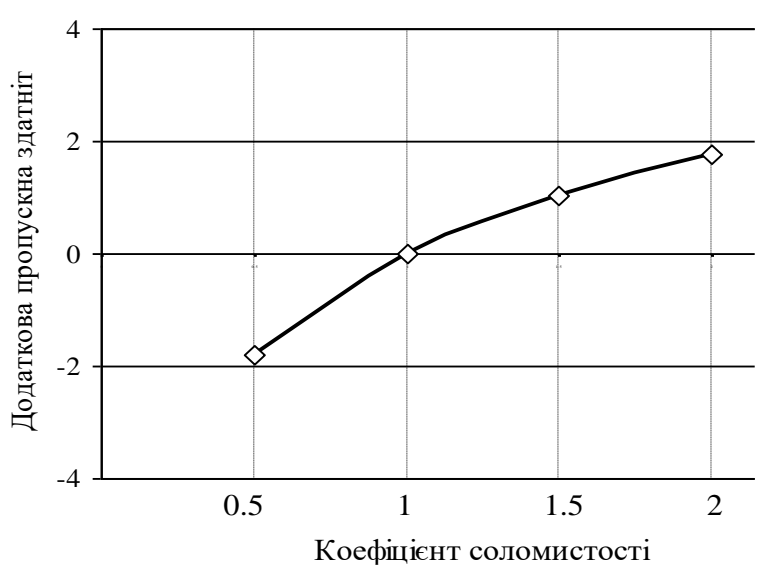

Рис. 5. Зміна додаткової пропускної здатності зернозбиральних комбайна від коефіцієнту соломистості

Крім того, встановлено характер зміни додаткової пропускної здатності агромашин від вологості маси, яка поступає до збиральної агромашини $\Delta q_{w}$ :

$$
\Delta q_{w}=3.18 \cdot \lg w-9.3291 .
$$

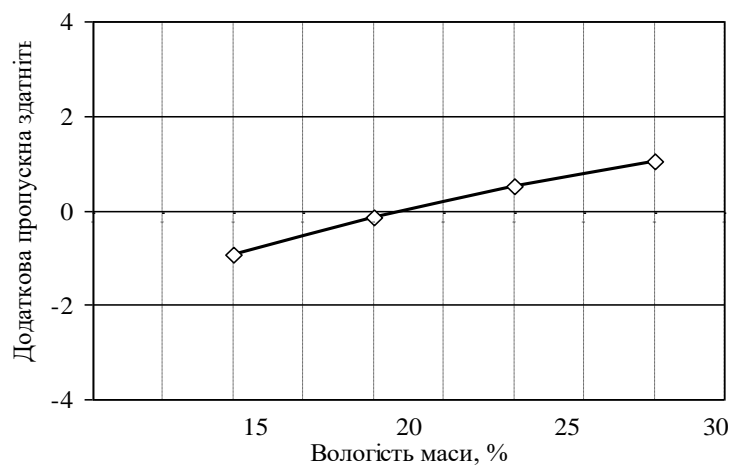

Рис. 6. Зміна додаткової пропускної здатності зернозбиральних комбайнів від вологості біологічної маси врожаю

Зі збільшенням вологості біологічної маси врожаю реальна пропускна здатність комбайна зменшується (рис. 6).
Таким чином, робоча швидкість збиральних агромашин, з врахуванням коефіцієнта соломистості та вологості маси, становить:

$$
V_{p}=\frac{36 \cdot\left(q_{3}+\left(\Delta q_{c}+\Delta q_{w}\right)\right)}{B_{p} \cdot\left(U_{3}+U_{c}\right)}, \text { км/год. }
$$

При умові $V_{p}>V_{\text {доп }}\left(V_{\text {доп }}\right.$ - допустима швидкість агромашинам за агротехнічними вимогами), уточнюють ширину захвату жатки, яка розраховується за наступною залежністю:

$$
B_{p} \leq \frac{36 \cdot\left(q_{3}+\left(\Delta q_{c}+\Delta q_{w}\right)\right)}{V_{\text {доп }} \cdot\left(U_{3}+U_{c}\right)}, \text { м. }
$$

Таким чином, параметри роботи збиральних агромашин погоджені зі станом агрокультур.

Висновки та перспективи подальших досліджень. Розглянуто підходи до обґрунтування алгоритмів визначення складу машинного парку необхідного для виконання механізованих технологічних операцій, на основі визнач ених типів робочих органів. Досліджено показники для агромашин, які забезпечують якісне виконання робіт.

Визначено фрактори, що впливають на реальну робочу швидкість виконання кожної механізованої технологічної операції та коефріцієнт використання ширини захвату агромашин.

Розглянуто фрактори що впливають на потужність необхідну для приводу робочих органів збиральних машин.

Все перелічене необхідно враховувати при створенні математичних моделей, для процесу вибору оптимального складу машинного парку, спираючись на попередньо визначені типи робочих органів.

\section{Література:}

1. Погорелый Л.В. Применение методов системного анализа при испытаниях сельскохозяйственной техники. Обзорная информ. / Л.В.Погорелый, В. В. Брей. - М.: В/О «Сельхозтехника». ЦНИИТЭИ, 1976. - 37 с.

2. Янковский И.Е. Системный анализ и оценка эфффективности работы сельскохозяйственных агрегатов на основе эксплуатационных испытаний. / И. Е. Янковский. - М.: В/О «Сельхозтехника». ЦНИИТЭИ, 1977. - 36 с.

3. Жак С.В. Методология и многоуровневые математические модели формирования и развития системы машин. Системный анализ в разработке механизированных сельскохозяйственных технологий. / С. В. Жак, О. А. Пенязев. // Сб. научн. трудов ВНИПТИМЭСХ. - 1984. - С. 13 - 23.

4. Тимофреев Ю.Е. Имитационное моделирование в задачах инженерного обеспечения сельскохозяйственного производства / Ю.Е. Тимофеев. // Системный анализ в разработке механизи- 
рованных сельскохозяйственных технологий: Сб. научн. трудов ВНИПТИМЭСХ. - 1984. - С. 29 - 36.

5. Липкович Э.И. Математическое моделирование системы машин для комплексной механизации сельскохозяйственного производства / Э.И. Липкович // Системный анализ в разработке механизированных сельскохозяйственных технологий: Сб. научн. трудов ВНИПТИМЭСХ. 1984. - С. 64 - 87.

6. Финн Э.А. Оптимизация эксплуатационных систем сельскохозяйственной техники : автореф. дис. на здобуття наук. ступеня докт. техн. наук: спец. 05.20.03 / Финн Э. А. - Новосибирск, 1989. - 40 с.

7. Саакян Д. Н. Система показателей комплексной оценки мобильных агрегатов / Д.Н. Саакян. - Москва: Машиностроение, 1969. - 256 с.

8. Диденко Н. К. Обоснование состава комплексов машин для растениеводства / Н.К. Диденко, В.Д. Гречкосей, И.И. Мельник. // Механизация и электрификация сельского хозяйства. 1980. - №9. - С. 4 - 5.

9. Оптимізація комплексів машин і структури машинного парку та планування технічного сервісу. Навчальний посібник. / [І.І. Мельник, В.Д. Гречкосій, В.В. Марченко та ін.]. - Київ: Видавничий центр НАУ, 2001. - 48 с.

10. Інженерний менеджмент. Навчальний посібник / [І.І. Мельник, І.Г. Тивоненко, С.Г. Фришев та ін.]. - Вінниця: Нова книга, 2007. - 536 с. Інженерний менеджмент. Навчальний посібник / [I. І. Мельник, І. Г. Тивоненко, С. Г. Фришев та ін.]. Вінниця: Нова книга, 2007. - 536 с.

11. Скільки води потрібно, щоб зерно проросло [Електронний ресурс] // growex.ua. - 2018. Режим доступу до ресурсу: https://growex.ua /ua/blog/skilki-vodi-potribno-shhob-zerno-proroslo

12. Фізичні властивості грунту [Електронний pecypc] // collectedpapers.com.ua. - 2015. - Режим доступу до ресурсу: https://collectedpapers. com.ua/soil_science/fizichni-vlastivosti-gruntu.

\section{References:}

1. Pogorelyj L.V. \& Brej V. V. (1976). Application of system analysis methods for testing agricultural machinery. Survey inform. Agricultural equipment. Moscow, USSR.

2. Yankovskij I. E. (1977). System analysis and assessment of the efficiency of agricultural units based on field tests. Agricultural equipment. Moscow, USSR.

3. Zhak V.S. \& Penyazev A.O. (1984). Methodology and multi-level mathematical models of the formation and development of a system of machines. System Analysis in the Development of Mechanized Agricultural Technologies., 13 - 23.

4.Timofeev Y.E. (1984). Simulation modeling in the tasks of engineering support of agricultural production. System Analysis in the Development of Mechanized Agricultural Technologies, 29 - 36.

5. Lipkovich E.I. (1984). Mathematical modeling of a system of machines for complex mechanization of agricultural production. System Analysis in the Development of Mechanized Agricultural Technologies, 64 - 87.

6. Finn, E. A. (1989). Optimization of operational systems of agricultural machinery (dissertation). Novosibirsk, USSR.

7. Sahakyan D.N. (1969). The system of indicators for the integrated assessment of mobile units. Moscow, USSR: Engineering.

8. Didenko N.K., Grechkosey V.D., \& Melnik I.I. (1980). Justification of the composition of machine complexes for crop production. Mechanization and Electrification of Agriculture, 9, 4 - 5.

9. Melnyk I.I., Grechkosiy V.D. \& Marchenko V.V. (2001). Optimization of machine complexes and structure of machine park and planning of technical service. Tutorial. Kyiv, Ukraine: NAU Publishing Center.

10. Melnyk I. I., Tyvonenko I. G., \& Frishev S. G. (2007). Engineering management. Textbook. Vinnytsia, Ukraine: New book.

11. How much water is needed for the grain to germinate. (2018, November 22). Retrieved from https://growex.ua/ua/blog/skilki-vodi-potribno-shhob-zerno-proroslo

12. Physical properties of soil. (2015). Retrieved from https://collectedpapers.com.ua/soil_science/ fizichni-vlastivosti-gruntu

\section{Аннотация}

\section{Обоснование и выбор агромашин по выбранным рабочим органам}

\section{В.Н. Зубко}

Рассмотрены подходы к обоснованию алгоритмов определения состава машинного парка необходимого для выполнения механизированных технологических операций, на основе определенных типов рабочих органов. Исследованы показатели для сельскохозяйственных машин, которые обеспечивают качественное выполнение основных технологических операций: ширина захвата, кинематическая длина и ширина, рабочая скорость, сопротивление агрегатированию, мощность на привод рабочих органов. 
Определены факторы, влияющие на реальную рабочую скорость выполнения каждой механизированной технологической операции и коэффициент использования ширины захвата сельскохозяйственной машины. Реальная рабочая скорость выполнения каждой механизированной технологической операции зависит от состава машинного агрегата.

Ширина захвата сельскохозяйственных машин зависит от размеров полей, их конфигурации, длины гона, наклона местности и конструктивной ширины захвата. Коэффицциент использования ширины захвата сельскохозяйственных машин зависит от вида операции, типа рабочего органа и от ограничений по агротехническим требованиям. Анализ проведенных исследований показывает, что зависимость коэффициента использования ширины захвата пахотного агрегата зависит от скорости выполнения операции и имеет квадратичный характер. Для машин, которые вносят средства защиты растений или проводят подкормку по листу, коэффициент использования ширины захвата зависит от высоты установки фрорсунки над поверхностью почвы и угла распыления жидкости.

Рассмотрены факторы, влияющие на мощность необходимую для привода рабочих органов уборочных машин.

Все перечисленное необходимо учитывать при создании математических моделей, для процесса выбора оптимального состава машинного парка, опираясь на предварительно определенные типы рабочих органов.

Ключевые слова: агромашина, рабочая скорость, технологическая операция, мощность, рабочий орган.

Abstract

\section{Justification and selection of agricultural machines based on selected working parts}

\section{V.N. Zubko}

The approaches to the substantiation of algorithms for determining the composition of the machinery necessary for the implementation of mechanized technological operations based on certain types of working parts are considered. The indicators for agricultural machines that provide high-quality performance of the basic technological operations are studied: working width, kinematic length and width, working speed, aggregation resistance, drive power of working parts.

The factors affecting the actual working speed of each mechanized technological operation and the utilization factor of the width of the capture of the agromachine are determined. The actual working speed of each mechanized technological operation depends on the composition of the machine unit.

The width of the agricultural machines depends on the size of the fields, their configuration, the length of the headland, the slope of the terrain and the design width of the capture. The utilization rate of the working width of agricultural machines depends on the type of operation, the type of working part and the restrictions on agricultural requirements. An analysis of the studies shows that the dependence of the utilization rate of the working width of the arable unit depends on the speed of the operation and has a quadratic character. For machines that introduce plant protection products or feed the sheet, the utilization rate of the working width depends on the height of the nozzle above the surface of the soil and the angle of liquid spray.

The factors affecting the power required to drive the working bodies of harvesting machines are considered.

All of the above must be taken into account when creating mathematical models for the process of choosing the optimal composition of the machine park based on the type of working parts.

Keywords: agricultural machine, working speed, technological operation, power, working parts.

Бібліографічне посилання/ Bibliography citation: Harvard

Zubko V. (2020). Justification and selection of agricultural machines based on selected working parts. Engineering of nature management, (1(15), pp. 36 - 43.

Подано до редакції / Received: 22.01.2020 